\title{
ACADEMIC QUALITY AND STUDENTS PERFORMANCE IN THE NIGERIAN TERTIARY EDUCATION: LESSONS FROM A PRIVATE FAITH-BASED UNIVERSITY IN SOUTH-WEST, NIGERIA (2010-2015)
}

\author{
Jide Ibietan ${ }^{1}$, Segun Joshua ${ }^{1}$, Dominic Azuh ${ }^{2}$ \\ ${ }^{1}$ Department of Political Science and International Relations, Covenant University (NIGERIA) \\ ${ }^{2}$ Department of Economics and Development Studies, Covenant University (NIGERIA)
}

\begin{abstract}
The pivotal role of education as a driver of economic growth and development in any country cannot be over-emphasised. To achieve this, academic quality and students' performance as intertwining variables in tertiary education must be deliberately contemplated. The absence of academic quality has obvious negative effects on students' performance, which ultimately casts aspersions on the knowledge base of a society. The narrative on university education in Nigeria highlights gaps in the delivery of triad objectives of teaching, research and community impact, and this is concomitant with allegation of graduates' unemployability resulting from poor training and skills deficits. It is predicated on these, that this paper examines the impact of academic quality on students' performance with a focus on the University under reference between 2010 and 2015. With a reliance on secondary data, backed by the descriptive analytical approach, the paper observes that the University operates a departure philosophy based on its unique mission which radically altered the Nigerian tertiary educational landscape from inception. Continuous compliance with internal and external quality mechanisms and sustained infrastructural investments with excellent support services are seriously advocated.
\end{abstract}

Keywords: Academic; Education; Performance; Quality; Tertiary.

\section{INTRODUCTION}

The indispensability of academic quality or qualitative education at the tertiary level to the students' performance is underscored by the application of a nation's knowledge base to solving societal myriad of problems. It is germane to state that academic quality is a booster of learner's cognitive development, and nurtures in the learner, values and attitudes for the responsible citizenship, emotional and creative development [1]

It is noteworthy that academic quality and students' performance in tertiary education are vital determinants of a nation's human resource base, quality and development. It is affirmed with a great deal of justification that no nation can develop beyond the quality of its higher education and the need for global competitiveness has impacted tremendously on higher education [2], especially in Nigeria. Higher education refers to "all forms of post-secondary education offered in universities, polytechnics, colleges of education and their equivalents" [3].

In a related discourse to the above, Njoku [4] averred thus:

Without doubt, Nigeria believed in and strived for universities that not only met national needs but also, compared in character and quality with the best in the world. Over time, however, we have noticed that many of Nigeria's... universities have taken a dip in quality and there is doubt today about the place of Nigerian universities among the comity of world universities.

Corroborating the above state of affairs, Effah [5] documented copiously on the golden years of higher education in Nigeria which were modelled on the British tradition and insistence on high standards but submitted that "...owing to a combination of factors, the situation could not be sustained". Effah [5] building on the works of Albert [6] highlighted the state of university education based on the gaps in its core functions of teaching, research and community service. These are some of the manifestations of dysfunctional university education as identified by Albert [6]: Consistent employability of graduates due to lack of skills; undue focus on theory than practice; falling quality of $\mathrm{PhD}$ theses; non-teaching of research writing skills and sheer lack of commitment on the part of students. 
To be sure, academic quality incorporates resource input and output which is a measure of internal and external efficiency of a university. Academic quality as a measure of student performance comprises indices such as achievement on tests, scores, pass rates and progression. It is therefore not surprising to observe that the dimensions for quality in students' performance or output are measures of achievement, attainment and standards [7]. Achievement connotes acquired knowledge, skills and attitudes learnt by students while attainment translates to academic progression, completion and obtaining qualifications in the chosen academic programme by the students. Standards on the other hand, refer to official learning objectives and outcomes from the university system.

Students' performance as a function of academic quality depends largely on quality of infrastructure or physical facilities which supports learning, quality of academic programmes and quality of academic staff. It is instructive to note that these (three factors) conjointly underline or constitute the major planks upon which the accreditation exercises are based by the regulatory agency (National Universities Commission) in Nigeria.

The paper is segmented as follows: Abstract; Introduction; Conceptual Clarification; section three chronicles the Internal and External Quality Mechanisms and Students Performance in the Private Faith-Based University; section four concludes the paper and draws lessons from the Quality Practices of the University. Predicated on quantitative and qualitative data, backed by descriptive analysis, the paper aims to establish the relationship between academic quality and students' performance using the private faith-based university in South-West, Nigeria as focus.

\section{CONCEPTUAL CLARIFICATION}

In this section, we shall explain the concepts of Quality; Academic Quality and Students Performance.

\subsection{The Concept of Quality}

Quite often, the concept of quality lends itself to semantics. This implies that, depending on academic or professional orientation and inclination, scholars or practitioners tend to define it differently or associate it with various meanings arising from its multidimensionality. On a general note, quality refers to the standard of how good, something is as measured against other similar things, or general excellence; the distinctive feature of something. More specifically, Obadara and Alaka [2] affirmed that quality can be defined as "fitness for purpose". They averred further that, "it encapsulates the ... meeting of commonly agreed precepts or standards. Such standards may be defined by law, an institution, a coordinating body or a professional society". The latter part of this definition illuminates our understanding of academic quality in higher education, especially in the Nigerian higher or university education system where the regulatory agency (NUC) prescribes relevant standards to maintain quality.

With respect to tertiary education in Nigeria, Obasi [7] discusses quality in terms of infrastructure or physical facilities; academic programmes and academic staff. Okebukola [8] corroborated that "quality should be the hallmark of African universities..." He stretched the argument further thus, "of concern should be the quality of the input (e.g. students, staff, facilities and curriculum), process (e.g. teachinglearning interactions, management and use of resources) and outcomes (knowledge, skills and attitudes of the graduates)". In order to achieve or drive these attributes, quality assurance must be built into all aspects of operations.

The above introduces a corollary of quality which is (the need to consistently maintain quality) known as quality assurance. It refers to meeting product specification or getting things done in the right way all the time. When applied to the university system, quality assurance are mechanisms built into institutions to meet expectations and criteria relating to academic matters, staff-student ratios, staff mix, staff development, physical/infrastructural facilities, library facilities and funding among others [2]. In the quest to attain world class standards or internationalisation, quality assurance is a major component and platform that Nigerian universities can leverage on.

\subsection{The Concept of Academic Quality}

As important as the issue or concept of academic quality is to the university system, scholars have observed that it is a relative concept. Notable among them is Obasi [7] who observed that notwithstanding the relativity of the concept, there are acceptable indicators of a high quality programme. He noted that the result of periodical and regular exercises conducted by the regulatory 
agency (NUC) in Nigeria offer the most objective and reliable available evidence of academic quality. For example, a programme declared to be of low academic quality in any Nigerian university stand the risk of being suspended and incapable of admitting students until appropriate remedial measures/requirements for effective teaching and learning as suggested by NUC are put in place.

Academic quality, according to Njoku [4] translates to excellence in education, and encapsulates "the content and organisation of undergraduate, graduate and professional instruction... for students". The attainment and sustenance of this goal, according to this author requires "outstanding faculty, high quality teaching and other instructional activities/facilities as highlighted (in the preceding section) by [7], which also converges with the views of Obasi [7]. Academic quality with reference to a university system connotes the ability or extent to which it conforms to established standards and appropriateness of inputs for delivery and relevance of academic programmes and output to meet labour market and societal needs.

Okebukola [8] identified the objectives of academic quality and rating mechanisms for higher education to include the following: to ensure that the performance of higher education institutions can be compared against a set of criteria, noting the unique context and challenges; allow for objective measure of performance; effective competition in similar systems; creating cases for review in line with global best practices; the minimum standards for earning degrees are similar in all institutions, and this refers to Benchmark Minimum Academic Standards (BMAS).

The quality of academic staff occupies an important place in the tripod for measuring academic quality. This explains the position of Obadara and Alaka [2] that "a tertiary institution is only as good as the quality of its teaching staff, they are the heart of the institution that produces its graduates, its research products" and community service. They submitted with finality that "the success and competitiveness of graduates ... will be affected by those standards and expectations". This explains why the possession of $\mathrm{PhD}$ degree with relevant years of experience became a minimum condition for promotion to Senior Lecturer position in the Nigerian university system from 2005 [3]. This situation many have found expression in the views of Robinson and Mcmillan in Schulze [9] that Academics without doctoral degrees "generally operate at the periphery of the academic community and are often viewed as 'apprentices' in the research community". Whereas, Academics with doctoral degrees "demonstrate that they can make significant contributions to their disciplines and... prove themselves at the highest level". The doctorate therefore socialises such Academics into the academic community. All things being equal, it is expected that academic quality will impact positively on students' performance in higher education.

\subsection{The Meaning of Students Performance}

The word 'performance' is a noun and it is defined as the action of performing or the capabilities of a machine or product. The first part of this definition does not help our understanding/meaning of performance, especially by its repetitive use of 'performing' in that definition. This makes it compelling to turn to the verb "perform" which means to carry out or complete an action or function. It also means functioning or doing something to a specified standard. The combination of the latter part of the definition with that of the second when applied to students as reflected in the theme of the paper translates to the capabilities of students to function and attain learning outcomes up to specified standard.

Writing on a related subject, Obadara and Alaka [2] emphasized the place of student's performance as a function of academic quality and resource output to include "academic achievement on tests, scores and progression/pass rates". These translate to internal and external efficiency. Students' performance is measurable in terms of learning achievement, attainment and standards, where achievement comprises the knowledge, skills and attitudes acquired by the student. Attainment translates to the number of students completing prescribed academic programmes and obtaining qualifications. Standards imply official learning objectives in terms of societal and labour market expectations of the university system. In the last one or two decades in Nigeria, there arose enormous doubts as far as academic standard is concerned, with views and concerns tilting more towards declining standards and quality. This is corroborated by Odimegwu [1] that "the Nigerian education sector is, quite evidently, incapable of meeting the human capital development challenges of the nation."

The above state of affairs is typified by the following assertion: "Universities had reported poor correlation between performance in the classroom and UME Scores. This has contributed to the poor quality of university graduates in Nigeria" [9]. This development led to the introduction of post-UME 
screening in the 2005/2006 academic session, with the ultimate aim of ensuring that the best minds from the society are admitted to the universities and other tertiary educational institutions in Nigeria. The next section of the paper is devoted to a discussion of the impact of internal and external quality mechanisms on students' performance in the private faith-based university, South-West, Nigeria.

\section{ACADEMIC QUALITY MECHANISMS AND STUDENTS PERFORMANCE IN THE PRIVATE FAITH-BASED UNIVERSITY}

There are one hundred and forty-seven universities in Nigeria, with ownership spreading across and comprising Federal Government; State Governments; private secular and private faith-based. Our focus is however on one Christian faith-based university in South-West, Nigeria. It was established thirteen years ago, and seeks to inculcate sound Christian principles, as well as imparting quality knowledge in students. It is required that students of this university go through a developmental phase of being moulded and groomed for the demands of real life. The internal and external quality mechanisms that impact on students' performance are discussed hereunder.

The University aligns with the directive from the National Universities Commission (NUC) as the regulatory agency for university education in the adoption of post University Matriculation Examination (UME) as double filter in the admission process. The University's version of this examination, which has a written component and interview, is referred to as CUSAS, through which brilliant students are admitted. Fresh students' results are thoroughly screened to comply with the Joint Admissions and Matriculation Board's (JAMB) requirement and NUC Benchmark Minimum Academic Standards (BMAS) for Nigerian universities.

Students' resumption process and activities are largely ICT-driven and commences usually from the comfort of their homes. Fees are paid on-line and course registration is electronically-enabled. These makes for easy and effective allocation of students to halls of residence in good time and well ahead of resumption. Every aspect of school life is taken seriously based on efficient and effective residential and infrastructural facilities. Lectures are intensive based on secular and spiritual instructions. Spirituality is the arrow-head of the University's core values, which makes Discipline, another core value to be highly prized. Operating at the cutting-edge of technology allows for Course Compacts/outline and lecture materials, including tutorial kits to be deployed on the University portal (intranet) for easy download by all students. To make learning easy and comfortable, all students are equipped with Samsung mobile Tablets. Students are assessed in a minimum of two tests and take home assignments which constitute their Continuous Assessment (CA). All CA scripts are returned to students at least two weeks before each semester examination.

Students CA and Lecture Attendance scores are published two weeks before the commencement of examinations for objections and counter-claims to be resolved. Lecture attendance default (below $75 \%$ ) disqualifies students from writing examinations. Examination period ranges from three to four weeks, and rules of examination conduct/processes are appropriately enforced. Grading of scripts commences immediately after each paper is written. Within two weeks from the last date of examination, results are considered by Board of Examiners starting from the Department through the Colleges, Senate Business Committee to the University Senate. Every script is taken through a second reading process by another Lecturer to ascertain fairness, correctness and objectivity in grading. All final year question papers/scripts and projects are externally moderated. The University creates avenue/platform for result validation by students who are not satisfied with their results.

The University has a functional Quality Assurance and Academic Standards Committee that visits all academic departments or units to ascertain that National and Global best practices are maintained all the time. With the exception of two programmes with Interim Accreditation Status, the remaining thirty are fully accredited, and students are performing well as reflected in Tables 1 and 4 in the Appendix. Academic progression/graduation rate of students is not less than $85 \%-$ Refer to Tables 3 and 4 . The record of students' performance in external academic, professional examinations, and the Presidential Scholarship for First Class graduates in Nigeria as displayed on the University's website and other media bear eloquent testimony of academic quality in the University. Out of 438 Academic Staff in the University at the end of 2014/15 Session, not less than $20 \%$ are in the Professorial cadre, and 247 representing $56 \%$ have Doctorate degrees (Refer to Table 2). This is by far higher than the national average and better than the public universities in Nigeria as highlighted in the evidence below:

The Yakubureport also revealed that only about 43 percentof teaching staff have doctorate degrees. Only seven Universities have up to 60 percentof their teaching with 
PhDs...Kano State University which is 11 years old, has one Professor and 25 lecturers with PhDs, Kebbi State University has two Professors and five lecturers who have PhDs (Okebukola, 2015: 81).

The narrative by Okebukola [3] above is quite disturbing, but when compared with the situation and statistics presented from this private faith-based University in South West-Nigeria, it shows an impressive measure of academic quality which finds true expression in students' performance as reflected in Table 3 . The statements below which was credited to the university regulatory agency in Nigeria (NUC) also validated academic quality and students' performance in the University thus:

... it suffices to report that the NUC made the following observations: It was found that those private universities that have enrolled/graduated students are well on course towards producing quality graduates that are disciplined, have the fear of God, possess leadership qualities and are job creators rather job seekers...exhibited characteristics such as insistence on good quality teaching by the academic staff; maintaining stable calendar, maintaining cult-free campuses; engaging in large-scale infrastructural development; insistence on and enforcing discipline and attitudinal change on students [8]

\section{CONCLUSION/LESSONS FROM QUALITY PRACTICES OF THE UNIVERSITY}

The paper examined the impact of academic quality on students' performance in the Nigerian tertiary education system, with a special focus on a private faith-based university in South-West, Nigeria. The indices of academic quality and students' performance were highlighted. The paper observed the indispensable role of quality assurance through its mechanisms in sustaining academic quality and students' performance. The nature and challenges of the Nigerian tertiary education were discussed. The internal and external academic quality mechanisms and the impact on students' performance in the University used as focus of this paper received tremendous emphasis.

Any university that aspires to attain high academic quality and excellent students' performance can emulate this University on compliance with internal and external quality (assurance) mechanisms. Such universities will further excel, if they adapt and sustain national and global best practices that take into consideration high standards and effective layers of filtering in the entire gamut of academic business/process starting from the pre-admission stage to the graduation of students as discussed in Section three of this paper.

The adoption, deployment and maximum utilisation of ICT in all facets of academic activities as practised in the University under reference is an irreducible minimum requirement for any university striving for top academic quality and impressive students' performance in the Twenty-First century.

The infrastructure, support services and funding of universities aspiring for global acclaim as manifested in academic quality and excellent students' performance must be adequate and reliable in order to attract and retain the best minds across the globe on its Faculty, especially at the Doctoral level and in the Professorial positions.

\section{REFERENCES}

[1] Odimegwu, F. B. O. (2005). Meeting the Challenges of Human Capital Development: The Case for Reforms in Our Educational Policies and Systems. Being Text of the University of Nigeria, Nsukka Convcation Address.

[2] Obadara, O. E. \& Alaka, A. A. (2013). Accreditation and Quality Assurance in Nigerian Universities. In Journal of Education and Practice. IISTE, USA. Vol. 4(8), pp 34-41.

[3] Okebukola, P. (2015). Higher Education and Africa's Future: Doing what is Right. $10^{\text {th }}$ Convocation Distinguished Lecture of Covenant University, Ota.

[4] Njoku, P. (2012). Quality Imperatives and World Class Standards: Positioning Universities in Africa for the Twenty-First Century. In Obayan, A; Awonuga, C; and Ekeanyanwu, N. (eds.). The Idea of a University. Ota: Covenant University Press. Pp 152-186.

[5] Effah, P. (2013). Repositioning African Universities for Excellence: Theoretical and Practical Perspectives. $8^{\text {th }}$ Convocation Ceremony Distinguished Lecture Series of Covenant University, Ota. 
[6] Albert, I. O. (2010). 50 Years of University Education in Nigeria: Evolution, Achievements, and Future Directions. A Joint Publication of University of Ilorin and National Universities Commission, Abuja.

[7] Obasi, I. N. (2008). Private Higher Education and Public Policy in Africa: A Contrasting Case of Nigeria and Botswana. Germany: Cuvillier Verlag, Gottingen.

[8] Okebukola, P. (2012). Re-inventing the African University: Paradigm for Innovation and Change. In Obayan, A; Awonuga, C; and Ekeanyanwu, N. (eds.) The Idea of university. Ota: Covenant University Press. Pp 113-150.

[9] Schulze, S. (2013). Identities of Academics Lacking Doctoral Degrees: A Narrative Inquiry. In Kamla-Raj, Journal of Social Sciences. Vol. 35(1), pp 33-41. 


\begin{tabular}{|c|c|c|c|}
\hline $\begin{array}{c}\text { TABLE 1: NUC ACCREDITATION STATUS } \\
\text { OF UNDERGRADUATE PROGRAMMES } \\
\text { PROGRAMME }\end{array}$ & $\begin{array}{l}\text { ACCREDITATION } \\
\text { TYPE }\end{array}$ & $\begin{array}{l}\text { YEAR } \\
\text { VISITED }\end{array}$ & $\begin{array}{l}\text { MATURITY } \\
\text { YEAR }\end{array}$ \\
\hline Accounting & Full & 2014 & 2020 \\
\hline Banking \& Finance & Full & 2012 & 2017 \\
\hline Business Administration & Full & 2012 & 2015 \\
\hline $\begin{array}{l}\text { Industrial Relations \& Human Resource } \\
\text { Management }\end{array}$ & Full & 2012 & 2017 \\
\hline Marketing & Full & 2012 & 2017 \\
\hline English & Full & 2012 & 2017 \\
\hline French & Full & 2012 & 2017 \\
\hline Mass Communication & Full & 2009 & 2014 \\
\hline Sociology & Full & 2009 & 2014 \\
\hline Demography \& Social Statistics & Full & 2014 & 2020 \\
\hline Economics & Full & 2014 & 2020 \\
\hline International Relations & Full & 2009 & 2014 \\
\hline Policy \& Strategic Studies & Full & 2012 & 2017 \\
\hline Political Science & Full & 2009 & 2014 \\
\hline Chemical Engineering & Full & 2012 & 2017 \\
\hline Civil Engineering & Full & 2012 & 2017 \\
\hline Computer Engineering & Full & 2015 & 2020 \\
\hline Electrical \&Electronics Engineering & Full & 2012 & 2017 \\
\hline Information \&Communication Engineering & Full & 2012 & 2017 \\
\hline Mechanical Engineering & Interim & 2015 & 2017 \\
\hline Petroleum Engineering & Full & 2011 & 2016 \\
\hline Architecture & Full & 2012 & 2017 \\
\hline Building Technology & Full & 2015 & 2020 \\
\hline Estate Management & Full & 2012 & 2017 \\
\hline Biochemistry & Full & 2013 & 2020 \\
\hline Biology & Interim & 2015 & 2017 \\
\hline Microbiology & Full & 2013 & 2020 \\
\hline Industrial Chemistry & Full & 2012 & 2017 \\
\hline Computer Science & Full & 2012 & 2017 \\
\hline Management Information System & Full & 2012 & 2017 \\
\hline Industrial Mathematics & Full & 2012 & 2017 \\
\hline Industrial Physics & Full & 2012 & 2017 \\
\hline
\end{tabular}

Source: Academic Planning Unit, 2015 
TABLE 2: INSTITUTIONAL DATA

\begin{tabular}{|c|c|c|c|c|c|c|c|c|c|c|c|}
\hline \multirow[b]{2}{*}{$S / N$} & \multirow[b]{2}{*}{ STAFF } & \multicolumn{2}{|c|}{$2010 / 2011$} & \multicolumn{2}{|c|}{$2011 / 2012$} & \multicolumn{2}{|c|}{$2012 / 2013$} & \multicolumn{2}{|c|}{$2013 / 2014$} & \multicolumn{2}{|c|}{$2014 / 2015$} \\
\hline & & FEMALE & MALE & FEMALE & MALE & FEMALE & MALE & FEMALE & MALE & FEMALE & MALE \\
\hline 1 & $\begin{array}{l}\text { TOTAL NUMBER OF FULL-TIME } \\
\text { ACADEMIC STAFF }\end{array}$ & 103 & 260 & 115 & 261 & 142 & 295 & 154 & 284 & 150 & 288 \\
\hline 2 & \begin{tabular}{|ll} 
TOTAL NUMBER & OF \\
PROFESSORS & \\
\end{tabular} & 4 & 38 & 4 & 40 & 3 & 41 & 3 & 37 & 4 & 35 \\
\hline 3 & $\begin{array}{l}\text { TOTAL NUMBER OF ACADEMIC } \\
\text { STAFF WITH PH.DS }\end{array}$ & 27 & 150 & 34 & 170 & 35 & 149 & 45 & 174 & 57 & 190 \\
\hline 4 & $\begin{array}{l}\text { TOTAL NUMBER OF FOREIGN } \\
\text { ACADEMIC STAFF }\end{array}$ & 3 & 2 & 3 & 2 & 4 & 3 & 4 & 3 & 4 & 5 \\
\hline 5 & $\begin{array}{l}\text { TOTAL NUMBER OF SENIOR } \\
\text { NON-ACADEMIC STAFF }\end{array}$ & 138 & 164 & 127 & 162 & 141 & 191 & 152 & 193 & 155 & 185 \\
\hline 6 & $\begin{array}{l}\text { TOTAL NUMBER OF JUNIOR } \\
\text { NON-ACADEMIC STAFF }\end{array}$ & 84 & 164 & 106 & 169 & 80 & 131 & 77 & 130 & 74 & 133 \\
\hline
\end{tabular}

Source: Academic Planning Unit, 2015 


\begin{tabular}{|c|c|c|c|c|c|c|c|c|c|c|c|c|c|c|c|c|c|c|c|c|c|c|c|}
\hline \multicolumn{24}{|c|}{ TABLE 4: CUMULATIVE GRADUATION FIGURES FOR FIVE SESSIONS } \\
\hline \multicolumn{5}{|c|}{$2010 / 2011$} & \multicolumn{5}{|c|}{ 2011/2012 } & \multicolumn{5}{|c|}{$2012 / 2013$} & \multicolumn{5}{|c|}{$2013 / 2014$} & \multicolumn{4}{|c|}{$201 / 2015$} \\
\hline 1 st & $2 \mid 1$ & $2 \mid 2$ & 3 rd & & $1 \mathrm{st}$ & $2 \mid 1$ & $2 \mid 2$ & $3 \mathrm{rd}$ & & $1 \mathrm{st}$ & $2 \mid 1$ & $2 \mid 2$ & 3rd & & 1 st & $2 \mid 1$ & $2 \mid 2$ & $3 \mathrm{rd}$ & & 1 st & $2 \mid 1$ & $2 \mid 2$ & $3 \mathrm{rd}$ \\
\hline 12 & 47 & 34 & 12 & 105 & 10 & 46 & 25 & 4 & 85 & 16 & 52 & 42 & 5 & 115 & 11 & 39 & 12 & 8 & 70 & 123 & 564 & 435 & 124 \\
\hline 4 & 29 & 17 & 7 & 57 & 3 & 28 & 23 & 1 & 55 & 7 & 24 & 31 & 8 & 70 & & 11 & 18 & 6 & 35 & 21 & 179 & 214 & 68 \\
\hline 4 & 32 & 24 & 10 & 70 & 2 & 19 & 31 & 5 & 57 & 7 & 39 & 31 & 3 & 80 & 6 & 17 & 10 & 1 & 34 & 36 & 256 & 236 & 61 \\
\hline 1 & 11 & 11 & 3 & 26 & 1 & 12 & 12 & 2 & 27 & 1 & 18 & 23 & 3 & 45 & 1 & 12 & 13 & 2 & 28 & 8 & 107 & 102 & 26 \\
\hline 1 & 8 & 8 & 1 & 18 & 1 & 8 & 15 & 5 & 29 & 1 & 11 & 17 & 2 & 31 & 3 & 11 & 7 & 1 & 22 & 7 & 54 & 65 & 18 \\
\hline 9 & 53 & 25 & 10 & 97 & 12 & 49 & 35 & 5 & \#\# & 13 & 54 & 31 & 2 & 100 & 6 & 35 & 21 & 3 & 65 & 87 & 507 & 380 & 86 \\
\hline 1 & 17 & 18 & 5 & 41 & 2 & 8 & 15 & 1 & 26 & 1 & 24 & 17 & 2 & 44 & 1 & 21 & 8 & 2 & 32 & 11 & 144 & 139 & 24 \\
\hline \multirow[t]{5}{*}{4} & 24 & 38 & 18 & 84 & 2 & 34 & 31 & 7 & 74 & 4 & 24 & 52 & 17 & 97 & 3 & 21 & 19 & 1 & 44 & 23 & 213 & 296 & 98 \\
\hline & 4 & 8 & & 12 & & 4 & 10 & 3 & 17 & 2 & 9 & 11 & 2 & 24 & & 4 & 1 & 3 & 8 & 3 & 42 & 74 & 15 \\
\hline & 10 & 10 & 2 & 22 & & 11 & 21 & 2 & 34 & 1 & 11 & 16 & 2 & 30 & & 2 & 7 & 2 & 11 & 1 & 55 & 84 & 17 \\
\hline & & & & & & & & & & & & & & & & & & & & 0 & 20 & 15 & 11 \\
\hline & 10 & 14 & 2 & 26 & 1 & 10 & 13 & 4 & 28 & & 9 & 19 & 2 & 30 & & 8 & 12 & 3 & 23 & 1 & 57 & 91 & 20 \\
\hline \multirow[t]{3}{*}{1} & 6 & 3 & & 10 & 2 & 3 & 2 & & 7 & 1 & 1 & 1 & & 3 & & & & 1 & 1 & 6 & 12 & 8 & 1 \\
\hline & 27 & 28 & 9 & 64 & 6 & 24 & 25 & 4 & 59 & 1 & 19 & 22 & 7 & 49 & 1 & 12 & 22 & 4 & 39 & 11 & 192 & 255 & 54 \\
\hline & & & & & & & & & & & & & & & 1 & 3 & 5 & & 9 & 1 & 27 & 49 & 17 \\
\hline 1 & 14 & 11 & 5 & 31 & 1 & 17 & 12 & 5 & 35 & & 15 & 10 & 3 & 28 & & 13 & 15 & 3 & 31 & 10 & 121 & 124 & 33 \\
\hline 1 & 21 & 21 & 1 & 44 & 1 & 17 & 14 & 9 & 41 & 1 & 20 & 7 & 4 & 32 & 2 & 13 & 8 & & 23 & 12 & 131 & 108 & 25 \\
\hline \multirow[t]{2}{*}{1} & 27 & 11 & 2 & 41 & 2 & 25 & 31 & 5 & 63 & 2 & 22 & 26 & 1 & 51 & 2 & 30 & 16 & 1 & 49 & 10 & 204 & 193 & 36 \\
\hline & 7 & 9 & 6 & 22 & & 13 & 6 & & 19 & 2 & 9 & 20 & 2 & 33 & 1 & 14 & 11 & 2 & 28 & 3 & 48 & 57 & 10 \\
\hline 1 & 15 & 6 & 3 & 25 & & 8 & 20 & 10 & 38 & & 6 & 27 & 5 & 38 & 1 & 10 & 20 & 2 & 33 & 3 & 71 & 113 & 37 \\
\hline 6 & 24 & 12 & & 42 & 5 & 27 & 11 & 5 & 48 & 2 & 27 & 20 & 2 & 51 & 6 & 25 & 18 & 3 & 52 & 29 & 143 & 87 & 16 \\
\hline 2 & 8 & 13 & 4 & 27 & 1 & 16 & 18 & 6 & 41 & 5 & 27 & 20 & & 52 & 5 & 19 & 17 & 2 & 43 & 14 & 85 & 88 & 15 \\
\hline 3 & 32 & 22 & 10 & 67 & 2 & 23 & 20 & 2 & 47 & 4 & 21 & 22 & 4 & 51 & 3 & 31 & 14 & 1 & 49 & 42 & 240 & 209 & 54 \\
\hline 5 & 56 & 44 & 5 & 110 & 8 & 50 & 33 & 7 & 98 & 12 & 38 & 32 & 2 & 84 & 4 & 48 & 29 & 2 & 83 & 66 & 312 & 207 & 26 \\
\hline 4 & 25 & 24 & 8 & 61 & 2 & 22 & 27 & 6 & 57 & 6 & 27 & 23 & 4 & 60 & 6 & 30 & 13 & 3 & 52 & 35 & 214 & 212 & 60 \\
\hline
\end{tabular}

Source: Academic Planning Unit, 2015 
TABLE $3:$ 2010/2011 STUDENTS ENROLMENT BY FACULTY, SEX AND LEVEL OF COURSES

\begin{tabular}{|c|c|c|c|c|c|c|c|c|c|c|c|c|c|}
\hline \multirow{3}{*}{$\begin{array}{l}\frac{0}{\Phi} \\
\frac{\Phi}{\overline{0}} \\
ن\end{array}$} & \multirow{3}{*}{ Dept } & \multirow{3}{*}{ Programme } & \multicolumn{11}{|c|}{ UNDERGRADUATE } \\
\hline & & & \multicolumn{2}{|c|}{100} & \multicolumn{2}{|c|}{200} & \multicolumn{2}{|c|}{300} & \multicolumn{2}{|c|}{400} & \multicolumn{2}{|c|}{500} & \multirow[t]{2}{*}{ Total } \\
\hline & & & $\mathrm{F}$ & M & $\mathrm{F}$ & M & $\mathrm{F}$ & M & $\mathrm{F}$ & M & $\mathrm{F}$ & M & \\
\hline \multirow[t]{16}{*}{ CDS } & ACC & Accounting & 42 & 35 & 83 & 32 & 68 & 43 & 77 & 38 & & & 418 \\
\hline & BFN & Banking and Finance & 24 & 22 & 48 & 38 & 38 & 34 & 34 & 30 & & & 268 \\
\hline & BUS & Business Administration & 24 & 22 & 56 & 41 & 28 & 38 & 41 & 28 & & & 278 \\
\hline & & Industrial Relations and Human Resource Management & 22 & 13 & 32 & 19 & 21 & 11 & 22 & 5 & & & 145 \\
\hline & & Marketing & 23 & 20 & 32 & 19 & 18 & 15 & 21 & 22 & & & 170 \\
\hline & LNG & English Language & 23 & 3 & 26 & 7 & 27 & 4 & 24 & 3 & & & 117 \\
\hline & & French & & & 4 & & 7 & & 9 & 1 & & & 21 \\
\hline & MAC & Mass Communication & 33 & 8 & 51 & 14 & 60 & 8 & 59 & 10 & & & 243 \\
\hline & & Mass Communication(PRA) & 17 & 1 & & & & & & & & & 18 \\
\hline & PSY & Psychology & 22 & 14 & 20 & 10 & 29 & 6 & 22 & 17 & & & 140 \\
\hline & SOC & Sociology & 14 & 13 & 22 & 15 & 29 & 14 & 33 & 12 & & & 152 \\
\hline & ECO & Demography and Social Statistics & 17 & 9 & 22 & 10 & 19 & 11 & 14 & 5 & & & 107 \\
\hline & & Economics & 40 & 28 & 68 & 45 & 55 & 51 & 59 & 42 & & & 388 \\
\hline & PSI & International Relations & 39 & 11 & 37 & 22 & 42 & 18 & 49 & 12 & & & 230 \\
\hline & & Policy and Strategic Studies & 5 & 5 & 17 & 11 & 12 & 5 & 11 & 2 & & & 68 \\
\hline & & Political Science & 8 & 11 & 8 & 23 & 14 & 21 & 13 & 10 & & & 108 \\
\hline \multicolumn{3}{|c|}{ CDS TOTAL } & 353 & 215 & 526 & 306 & 467 & 279 & 488 & 237 & 0 & 0 & 2871 \\
\hline \multirow[t]{18}{*}{ CST } & $\mathrm{CHE}$ & Chemical Engineering & 28 & 34 & 26 & 50 & 20 & 44 & 13 & 35 & 20 & 31 & 301 \\
\hline & CVE & Civil Engineering & 10 & 49 & 11 & 67 & 8 & 50 & 3 & 40 & 5 & 28 & 271 \\
\hline & EIE & Computer Engineering & 9 & 54 & 23 & 59 & 15 & 53 & 13 & 40 & 20 & 56 & 342 \\
\hline & & Electrical and Electronics Engineering & 10 & 68 & 18 & 93 & 15 & 91 & 18 & 78 & 21 & 103 & 515 \\
\hline & & Information and Communication Engineering & 18 & 46 & 29 & 56 & 21 & 46 & 31 & 28 & 23 & 46 & 344 \\
\hline & MCE & Mechanical Engineering & 9 & 54 & 3 & 75 & 7 & 57 & 4 & 48 & 3 & 47 & 307 \\
\hline & PET & Petroleum Engineering & 20 & 34 & 24 & 61 & 15 & 40 & 25 & 44 & 14 & 32 & 309 \\
\hline & ARC & Architecture & 15 & 49 & 18 & 47 & 20 & 50 & 21 & 34 & & & 254 \\
\hline & BLD & Building Technology & 13 & 27 & 8 & 26 & 12 & 25 & 8 & 14 & 6 & 16 & 155 \\
\hline & ESM & Estate Management & 17 & 30 & 26 & 28 & 16 & 25 & 16 & 20 & 13 & 14 & 205 \\
\hline & $\mathrm{BIO}$ & Biochemistry & 24 & 8 & 35 & 16 & 27 & 7 & 35 & 10 & & & 162 \\
\hline & & Biology & 9 & 1 & 8 & 1 & 7 & 4 & 3 & 3 & & & 36 \\
\hline & & Microbiology & 19 & 6 & 44 & 15 & 36 & 10 & 38 & 8 & & & 176 \\
\hline & $\mathrm{CHM}$ & Industrial Chemistry & 16 & 14 & 16 & 27 & 16 & 20 & 19 & 12 & & & 140 \\
\hline & $\mathrm{CIS}$ & Computer Science & 19 & 40 & 34 & 86 & 27 & 70 & 37 & 54 & & & 367 \\
\hline & & Management Information System & 31 & 36 & 48 & 56 & 40 & 55 & 47 & 48 & & & 361 \\
\hline & MAT & Industrial Mathematics & 3 & 11 & 6 & 21 & 12 & 14 & 6 & 11 & & & 84 \\
\hline & PHY & Industrial Physics & 15 & 54 & 9 & 57 & 11 & 45 & 2 & 16 & 0 & 0 & 209 \\
\hline \multicolumn{3}{|c|}{ CST TOTAL } & 285 & 615 & 386 & 841 & 325 & 706 & 339 & 543 & 125 & 373 & 4538 \\
\hline $\begin{array}{l}\text { Grand } \\
\text { Total }\end{array}$ & & & 638 & 830 & 912 & 1147 & 792 & 985 & 827 & 780 & 125 & 373 & 7409 \\
\hline
\end{tabular}

Source: Academic Planning Unit 2015 